\title{
Corporate Social Responsibility as a Differentiation Tool to Achieve Competitive Advantage; Cases from Turkish Private Sector
}

[ Murat Yalçıntaş ]

\begin{abstract}
This paper aims to present Corporate Social Responsibility (CSR) as a differentiation tool to achieve competitive advantage. Two fundamental outcomes of CSR activities; corporate reputation and organizational commitment can become sources of competitive advantage for a company using CSR as a differentiation tool. This paper discusses the theoretical side of this approach and identifies successful applications of CSR differentiation strategies by examining cases from some Turkish companies. The findings indicated that CSR activities provided valuable resources to the companies such as positive reputation, increased brand value, committed workforce and "free" advertisement provided by the media. The paper concludes that CSR can be a valuable tool for differentiation strategies and can help companies to achieve competitive advantage.
\end{abstract}

Keywords-Corporate Social Responsibility, CSR, Competitive Advantage, Differentiation, Strategic Management

\section{Introduction}

During the 20th century the purpose of a business was believed to be maximizing shareholder wealth. Today, with the emergence of the Corporate Social Responsibility (hereafter CSR) concept, this view of business is recognized to be mistaken. From the perspective of the stakeholder theory, nowadays managers seek the long term sustainability of their organization and try to generate the most value for the broadest section of the society. But there are still question marks on how the CSR performance of a company can be measured and how a company's CSR activities influence its performance [1]. That is why some managers believe that CSR is not in the best interests of the company and as a result they are unwilling to act for the benefit of the greater society.

This paper argues that CSR can be of strategic value to the company and examines cases of Turkish for-profit companies where the company differentiates itself by CSR activities. According to the cases, CSR projects provide competitive advantage in brand management and human resources. Although all of these cases can not be considered as examples of strategic CSR, i.e. the use of Corporate Social Responsibility to acquire value for the company [2], they still prove that successful applications can become a source of competitive advantage for a company using CSR as a differentiation tool.

Murat Yalçıntaş

İstanbul Ticaret Üniversitesi

Turkey

\section{Conceptual Background}

\section{A. CSR and Competitive Advantage}

$\mathrm{CSR}$, a concept calling corporations to be ethical and to promote the virtues of good corporate citizenship, as well as to obey the law while striving to make profit [3], is not only significant in discussing the role of the business in the society but also in helping the business to achieve competitive advantage. European Union defines CSR as "the responsibility of enterprises for their impact on society [4]. Even tough this approach considers the private governance of corporate externalities (positive and negative effects of corporations on society and the environment) as the central theme of the CSR, it is also a business practice that can provide competitive advantage to the organizations. That is why CSR is also viewed as a change-management project with far-reaching implications for markets, business practice, and entrepreneurship [5].

A company can earn a rate of profit in excess of its cost of capital as long as the industry in which it operates is profitable enough and as long as it has a competitive advantage over its rivals. A competitive advantage exists when a company delivers the same goods as its competitors but at a lower cost (cost advantage), or delivers goods that exceed those of competitors (differentiation advantage). According to Resource Based Theory (RBT), the primary source of a company's competitive advantage is its capabilities, ie; capacity of its resources to perform a task. RBT also argues that competitive performance of a company is primarily determined by its internal resources. Barney (2002) claims that to achieve a sustainable competitive advantage, a company should develop competencies (crossfunctional integration and coordination of capabilities) which are valuable, rare, and difficult to imitate and fit to the organization [6]. These competencies can mostly be developed by the positive differentiation of intangible resources.

A company pursuing a differentiation strategy is able to achieve a competitive advantage over its competitors by building customer and brand loyalty. Differentiation strategy is usually developed around competencies such as product quality, technology and innovativeness, reliability, brand image, firm reputation, durability, and customer service, which must be difficult for rivals to imitate [7]. Wang et al. (2011) discusses the technology and innovation, human resources, and organizational structure as the sources of competitive advantage for a differentiation strategy.

Since CSR activities can deliver valuable competencies to the company such as positive reputation, increased brand value and "free" advertisement provided by the media, Mc Williams \& Siegel (2011) considers CSR as a resource in 
the RBT sense and claims that "a CSR strategy can be a valuable (in the RBT sense) complement to a differentiation strategy, enhancing the value of the reputation and/or the brand of the company" [8]. Two fundamental outcomes of CSR activities; corporate reputation and organizational commitment can become sources of competitive advantage for a company using CSR as a differentiation tool.

Corporate reputation is an invisible or non-physical resource that cannot be imitated or replaced and that is unique, rare and valuable. Positive corporate reputation is a performance indicator, a competition factor and a competition advantage in itself. The biggest contribution of corporate reputation to businesses is an advantage in sustainable growth and competition. Corporate reputation gives organizations advantages for selling their products for higher prices, requesting low prices in procurement of raw material and intermediate products, consumer and employee loyalty, increase in overall incomes and overcoming crisis periods easily.

Human resources can become a source of competitive advantage for a differentiation strategy provided that the employees have certain characteristics which permit them to excel over the competitor's workforce. One of these characteristics are their organizational commitment. Commitment is one of the 4-Cs (Commitment, Congruence, Competence, Cost effectiveness) in the Harvard model of Human Resource Management [9]. It is regarded as an immediate and, perhaps, the most critical outcome of human resource strategy. In this model, employees' commitment is seen as the key factor in achieving competitive performance [10].

\section{B. Differentiation through CSR}

Corporate reputation and organizational commitment are two powerful differentiation tools which can be achieved through CSR.

Corporate reputation has been defined as "a perceptual representation of a company's past actions and future prospects that describe the firm's overall appeal to all its key constituents when compared to other leading rivals" [11] or in other words as "the entirety of all emotional responses that the company's employees, customers, investors and the public have to the business' name, such as good or bad, weak or strong" [11]. Fombrun and Shanley define corporate reputation as the public's evaluations and judgements of all times and broaden the definition as meeting the stakeholders' expectations [12]. The concept of corporate social responsibility is defined as businesses taking stakeholders' expectations into consideration while organizing their activities. In this sense, the corporate reputation can be defined as the public's perception of the business' social responsibility activities. Businesses' social responsibility policies have an important role in constituting their corporate reputation, since reputation is the value of the relation that the business has with the stakeholders, in the eyes of the stakeholders. Considering that businesses' relations and interactions with stakeholders are shaped by the concept of social responsibility, the close link between social responsibility and corporate reputation is evident. While evaluating the businesses, stakeholders take social responsibility activities into consideration and evaluate businesses' social performance. Thus, social responsibility activities constitute and support businesses' corporate reputation. Studies showed that factors such as social and ecological environmental sensitivity, product service quality, internal/external customer satisfaction, which are seen as social responsibility parameters, are linked to corporate reputation and that organizations' social responsibility activities increase corporate reputation [13]. The said relation is so evident that some researchers prefer using social responsibility parameters for measuring businesses' reputation [14].

There are studies providing evidence that more socially responsible corporations are more attractive to potential employees and that they may therefore benefit from larger applicant pools [15] [16], and that they may enjoy a more committed workforce because "employees will be proud to identify with work organisations that have favourable reputation" [17]. Brammer et al. (2007) investigated the relationship between employee perceptions of CSR and organisational commitment within a model which draws on social identity theory. They found out that external CSR was positively related to affective commitment and the contribution of CSR to affective commitment is at least as great as that of job satisfaction [18]. External corporate social responsibility has positive implications therefore not only to external stakeholders but also to the commitment of employees within the organisation. External CSR encompasses corporate philanthropy and community contributions and reflects a company's ethical stance towards consumers and other external stakeholders [19]. Allen and Meyer (1990) distinguish between three forms of organisational commitment: affective commitment which denotes "an emotional attachment to, identification with, and involvement in the organisation", continuance commitment which reflects "the perceived costs associated with leaving the organisation" and normative commitment "which reflects a perceived obligation to remain in the organisation" [20].

\section{CSR in Turkey}

The concept of corporate social responsibility in the modern sense has been in Turkey's agenda mainly for the last decade. In Turkey, as in many parts of the world, this concept has its roots in a culture of philanthropy, often associated with traditions and religion. In the Ottoman Empire era, charitable foundations for education, healthcare and religious services were significant actors in the society. The culture of these foundations was rooted in religious traditions. These traditions manifested themselves as Islamic alms and doles. Wealthy persons and families donated a portion of their riches or properties to the foundations, thus providing the needy part of the society with various services. The modern Turkish Republic was founded in 1923. From the 1960s and on, Turkish charitable foundations started to emerge from conglomerating family companies. In the 1990 s, one of the main concerns of Turkish businessmen that acquired enough riches after the economic liberalization of 1980 s, was to have a good reputation in the eyes of the public. Therefore, charitable activities of these companies accelerated in the 1990s, such as Koç Holding, Eczacıbaş1 Holding and Sabanc1 Holding. These were acts of philanthropy made to have an honourable public image, rather than the sustainable development or strategic governance mentality that is the current dominant corporate social responsibility paradigm. Corporate social responsibility mentality in Turkey is still mostly on the 
philanthropy axis, due to the culture it came into being. Actually there are three basic intertwined reasons that push the private sector in Turkey to engage in corporate social responsibility acts, apart from the pressure of social stakeholders. The first reason is that in order to have a relative competitive advantage against the increasing global competition, Turkish companies are forced to undertake CSR projects which are usually not in the scope of their traditional commercial activities. The second reason is that corporate social responsibility has a significant place among the criteria that Turkey should meet in the European Union harmonization process. The third reason is the increasing number of regulations in this field [21].

The most concrete example of these regulations is the Corporate Governance Principles that the Capital Markets Board (SPK) of Turkey published in July 2003 and revised in February 2005. Corporate Governance Principles are comprised of four chapters; public disclosure and transparency, shareholders, stakeholders and board of directors [22]. The principles of corporate social responsibility acts are covered in the stakeholders chapter. Independent auditing institutions appointed by SPK evaluate the companies' compliance to these corporate governance principles and assigns a company compliance score. Another regulation, the "Corporate Governance Index", which entered into force in 2008, also encourages publicly-traded companies in Turkey to assume and report corporate responsibilities systematically, as a part of their corporate governance [23]. Thus, most of the companies traded in the Istanbul Stock Exchange Market (BIST) publish their code of ethics and corporate social responsibility strategies/activities on their websites. These companies focus their corporate social responsibility activities mainly on the environment, education, culture and art.

\section{Cases}

\section{A. Vodafone, Farmers' Club}

Vodafone is one of the world's leading mobile communications providers, operating in 26 countries and in partnership with networks in over 55 more. Across the world, Vodafone has almost 444 million customers [24].

In 2009, Vodafone Turkey's market share was only $18 \%$ and Turkey was Vodafone's least successful market. But today, it is a star in terms of best growth with a $28.5 \%$ market share. According to Serpil Timuray, the current Managing Director of Vodafone Turkey who took the office in 2009 this success stems from efforts for building a brand on trust. According to Timuray, trust can only be achieved through changing and improving the lives of the customers by assessing them outside their main fields of activity. It's not only providing them with telecommunication services but with solutions that make their lives easier, enable them to earn more money and help them do their jobs more consciously and safely. It is a total win-win situation: While the customers' socioeconomic lives improve, Vodafone's sales increase. A mutual trust is built. The Farmers' Club project is a living example for this policy. Vodafone regularly provides 700,000 farmers with weather forecast information through Farmers' Club on their mobile phones. It is a simple service; thanks to the SMS messages that reach every part of Turkey, shepherds can herd their animals to shelters in time during floods and storms. Furthermore, the
Farmers' Club offers a chance for direct contact between the buyers and the farmer, eliminating the middle-men Moreover, farmers are informed of the governmentsupported sectoral trainings and subsidies in the field of agriculture via Farmers' Club. Vodafone also organizes a lottery where member farmers have a chance to win a tractor [25].

Of course the recent success of Vodafone in the Turkish market can not be attributed only to the Farmer's Club project. But as Timuray puts forward, the project is a concrete example of the change of mentality in Vodafone Turkey, how Vodafone Turkey tried to build its branding on trust, how corporate reputation could be increased through a CSR project.

\section{B. Koç Holding, For My Country}

Founded in 1926, Koç Holding being the largest group of companies in Turkey and world's largest 341 th, employs more than 80,000 employees (2016) [26] [27]. The conglomerate is active in many sectors such as energy, automotive, finance, customer durables, construction and tourism.

"For My Country" project aims to awareness on social issues among Koç Group employees, distributors and suppliers. The theme of the project changes every 2 years and it is the largest community engagement project in Turkey. The scope of the Koç's For My Country CSR project, which serves as an umbrella for many sub projects, comprises the following [28];

- In 2006 and 2007, 387 local projects were conducted to support local development.

- In 2008 and 2009, in cooperation with TEMA Foundation and the Ministry of Forestry, seven For My Country forests were created around Turkey, $1,084,000$ saplings were planted and environmental education was provided to over 18,000 children in 81 provinces.

- In 2010 and 2011, through "Donating Blood for My Country" campaign, organized in cooperation with the Red Crescent, 103,000 people were informed and 83,579 units of blood donated in order to increase the number of volunteer and regular blood donors in Turkey.

- Between 2012 and 2015, with the objective to create a permanent impact in the working and social lives of the disabled, the "No Barriers for My Country" project was conducted in cooperation with the Alternative Life Association and the United Nations Development Program. Throughout Koç Group companies, 103,482 people attended Right Approach to Disability trainings. Through dealers acting as For My Country agents, 22,500 students were trained on the "Right Approach to Disability" in 36 provinces. Companies, dealers, branches and stores became disabled-friendly while products and services were developed for the disabled. 
On May 2015, the deceased Koç Holding Executive Board Chairman Mustafa V. Koç had said about the project: "The Koç Community is our country's largest family in terms of employees and distributors. If the members of this family are equipped with a belief in social responsibility, then that will have a significant role in raising the awareness on social issues in our country" [29]. With these words, Mr. Koç confirms that one the main targets of this project is to achieve a change of mentality in Koç Group employees. This change would raise the employees' awareness on social responsibility and would lead to an eventual increase on their organizational commitment. The results were outstanding; for example, between 2010-2011, Koç Group workers and dealers within «Donating For My Country» Project donated 84.000 units of blood, being the largest blood donation to Turkish Red Crescent. Between 20152017, 70,000 employees, 3,000 distributors and 8,000 local community members have participated in gender awareness trainings. A research conducted by the corporate communication department of Koç Holding revealed that between 2006-2017 the "free" advertisement provided by the media due to CSR projects reached nearly 430 million "people". Furthermore, the results of the Koç Holding surveys on workforce commitment and satisfaction demonstrates clearly the effect of the conglomerate's CSR projects on the employee's organizational commitment.

\section{Hürriyet Newspaper, No! To Domestic Violence Campaign}

Hürriyet newspaper, 69 years old now, is the flagship of Turkish media. From current affairs to celebrity stories, economy and politics coverage to sports news, approximately 1.6 million readers, printed and online, are following Hürriyet at present [30].

In 2004, the campaign was initiated as a social responsibility project of Hürriyet Newspaper in order to raise awareness regarding violence against family members, especially women and children, and to contribute to the solution of this problem. The project included [31];

- News, special supplements, booklets, brochures and posters with No! To Domestic Violence logo

- National and international conferences

- Güldünya Şarkıları (Songs) CDs, compiled together with 13 renowned female performers and 'Kadınlar Söylüyor (Women Are Singing)' concert, both of which are exclusive for the campaign. Male performers also appeared for 'Erkekler Söylüyor (Men Are Singing)' concert and compiled concert DVDs

- Nilüfer (a very famous woman pop singer) 12 Duets and Nilüfer 13 Duets Concerts with Nilüfer and rock bands. A concert performed by Le Div4s

- Advertising campaigns and public service announcements. Around 40 thousand people throughout Turkey were trained on raising awareness.
As the result of the campaign significant contribution was made for creating social sensitivity regarding domestic violence; this type of violence that once was seen as "familial situation" is now deemed as a crime. Furthermore the language and approach towards domestic violence against women changed in Turkish media. And also the state was prompted to come up with solution and protection; the law and circulars were amended, number of measures and women's shelters have been increased.

Hürriyet Newspaper's social responsibility project, No! to Domestic Violence has become a solution partner for the Ministry of Family and Social Policies. This demonstrates the reputation and the legitimacy that the newspaper has earned in the eyes of governmental institutions. As a part of the campaign, in 2007, a 24/7 emergency hotline was set up to provide legal, psychological and safety assistance to women subjected to ill treatment and violence. Between October 15, 2007 and October 1, 2013, 36,989 people called the hotline, 17,414 of which received legal, corporate or psychological assistance for domestic violence. People called the emergency hotline from all provinces of Turkey, 14 other countries (Germany, France, Austria, Azerbaijan, Belgium, the Netherlands, Australia, United States, Syria, Switzerland, Iran, Tunisia, England, Sweden) and Cyprus [31]. These numbers prove how much this project increased Hürriyet Newspaper's corporate reputation and social legitimacy and that its reliability is now far beyond that of a media outlet in the eyes of the public.

\section{Conclusion}

The cases support the theoretical approach that CSR can be used as a differentiation tool to reach competitive advantage. In the above examples, two fundamental outcomes of CSR activities; corporate reputation and organizational commitment became sources of competitive advantage and differentiated the companies. The findings indicated that CSR activities provided valuable resources to the companies such as positive reputation, increased brand value, committed workforce and "free" advertisement provided by the media.

This paper does not attempt to measure CSR performance of these companies nor how much the CSR activities influences their performance. The study rather identifies successful application of CSR projects in Turkey and argues that, although among the three cases only the Vodafone Turkey's approach could be labelled as strategic CSR, the other two company's CSR mentalities being mostly on the philanthropy axis, CSR projects successfully differentiated all of the companies. This differentiation could be observed by analysing latent variables such as employee mentality, company reputation, workforce commitment and brand reliability. If Koç Holding and Hürriyet Newspaper can, in the future, focus their CSR projects with a strategic approach by moving away from the philanthropy axis, they can also easily develop CSR based competencies for a more sustainable competitive advantage.

Since this study focuses on identifying cases and determining sources of competitive advantage, future research could introduce a more analytical approach by measuring outcomes of the CSR projects and by identifying a possible correlation between the outcomes and the competitive advantage parameters of the companies. 


\section{References}

[1] D. Chandler, Corporate Social Responsibility, A Strategic Perspective, New York: Business Expert Press, 2015.

[2] D. P. Baron, «Private Politics, Corporate Social Responsibility, and Integrated Strategy,» Journal of Economics and Management Strategy 10 (1), pp. 7-45, 2001.

[3] A. B. Carroll, The pyramid of corporate social responsibility: Toward the moral management of organizational stakeholders, Business Horizons, 1991

[4] European Commission, «Corporate Social Responsibility (CSR),» [Online]. Available: http://ec.europa.eu/growth/industry/corporatesocial-responsibility_en. [Retrieved: August 2017].

[5] K. Amaeshi, P. Nnodim ve O. Osuji, Corporate Social Responsibility, Entrepreneurship, and Innovation, New York: Routledge, 2015.

[6] J. Barney, Gaining and Sustaining Competitive Advantage, 2nd ed., Perentice Hall, 2002.

[7] A. Moses, «Business Strategy and Competitive Advantage in Family Businesses in Ghana: The Role of Social Networking Relationships,» in Conference on Entrepreneurship in Africa, 2010.

[8] A. McWilliams ve D. Siegel, «Creating and capturing value: strategic corporate social responsibility, resource-based theory, and sustainable competitive advantage» Journal of Management, 37(5), pp. 14801495, September 2011.

[9] M. Beer, B. Spector, P. Lawrence, M. Quinn ve R. E. Walton, Managing Human Assets, New York: The Free Press, 1984.

[10] M. G. Shahnawaz and R. C. Juyal, «Human resource management practices and organizational commitment in different organizations» Journal of the Indian Academy of Applied Psychology, 32(3), pp. 171178, 2006.

[11] C. Fomburn, Reputation: Realising Value from the Corporate Image, Harvard, MA: Harvard Business School Press, 1996

[12] C. Fomburn and M. Shanley, «What's in a name? Reputation building and corporate strategy» Academy of Management Journal, pp. 233$258,1990$.

[13] S. Brammer and S. Pavelin, «Building a good reputation» European Management Journal, (22)6, pp. 704-713, 2004.

[14] G. Dowling, «Corporate reputations: should you compete on yours?» California Management Review, (46)3, pp. 19-36, Spring 2004.

[15] D. B. Turban and D. W. Greening, «Corporate social performance and organizational attractiveness to prospective employees» Academy of Management Journal, 40, pp. 658-672, 1996.

[16] D. Greening and D. Turban, «Corporate social performance as a competitive advantage in attracting a quality workforce» Business and Society, (39)3, pp. 254-280, September 2000.

[17] D. K. Peterson, «The relationship between perceptions of corporate citizenship and organizational commitment»Business and Society, (43), pp. 296-319, 2004.

[18] S. Brammer, A. Millington and B. Rayton, «The contribution of corporate social responsibility to organizational commitment» The International Journal of Human Resources Management 18(10), pp. 1701-1719, 2007

[19] A. B. Carroll, «A three dimensional conceptual model of corporate performance» Academy of Management Review, 4, pp. 497-505, 1979.

[20] N. J. Allen and J. P. Meyer, «The measurement and antecedents of affective, continuance and normative commitment to the organization» Journal of occupational and organizational psychology 63(1), pp. 1-18, 1990

[21] S. Deren Van Het Hof and S. Hoştut, Kurumsal Sosyal Sorumluluk Kavramlar, Uygulama ve Örnekler, Ankara: Nobel Yayıncılık, 2015.

[22] Borsa İstanbul, «Kurumsal Yönetim,» [Online]. Available: http://www.borsaistanbul.com/sirketler/sirketlerinyukumlulukleri/gelisen-isletmeler-piyasasi/kurumsal-yonetim.
[Retrieved: August 2017].

[23] Borsa İstanbul, «Kurumsal Yönetim Endeksi» [Online]. Available: http://www.borsaistanbul.com/endeksler/bist-payendeksleri/kurumsal-yonetim-endeksi. [Retrieved: August 2017].

[24] Vodafone UK, «Company history» [Online]. Available: https://www.vodafone.co.uk/about-us/company-history/. [Retrieved: August 2017].

[25] Vodafone TR, «Vodafone Çiftçi Kulübü,» [Online]. Available: http://www.ciftcikulubu.com/. [Retrieved: August 2017].

[26] Koç Holding, «Tarihçe» [Online]. Available: http://www.koc.com.tr/tr-tr/hakkinda/tarihce. [Retrieved: August 2017].

[27] Hürriyet Newspaper, «Ekonomi» 21 January 2016. [Online]. Available: http://www.hurriyet.com.tr/koc-holding-dunya-devleriarasinda-40043353. [Retrieved: August 2017].

[28] Koç Holding, «Ülkem İçin» [Online]. Available: http://www.ulkemicin.com.tr/. [Retrieved: August 2017].

[29] Koç Holding, «Yönetim Mesajı» [Online]. Available: http://www.ulkemicin.com.tr/yonetim-mesaji. [Retrieved: August 2017].

[30] Hürriyet Newspaper, «http://www.hurriyet.com.tr/,» [Online]. Available: http://www.hurriyet.com.tr/. [Retrieved: August 2017].

[31] Hürriyet Kurumsal İletişim, «Sosyal Sorumluluk Projeleri,» Hürriyet, İstanbul, 2015.

About Author:

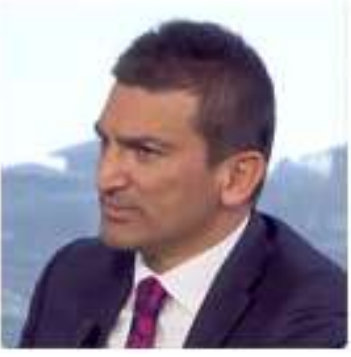

Assoc. Prof. Dr. Murat Yalçıntaş

Profession

Businessman/Academician

Position

Director of Foreign Trade Institute

Istanbul Commerce University Turkey

Education

Boğaziçi University, Faculty of Engineering, Mechanical

Engineering, Undergraduate Degree

Boston \& Vrije Universities, MBA

Istanbul University, School of Business Administration, Ph.D. Previous Positions

President of Istanbul Chamber of Commerce President of the Association of the Mediterranean Chambers of Commerce and Industry (ASCAME)

Vice-President of the Union of Chambers and Commodity Exchanges of Turkey (TOBB)

President of the Tourism Development and Education Foundation (TUGEV)

Vice-President of Justice and Development Party (AKP) Istanbul Branch / Member of Founders' Committee

Islamic Development Bank, Project Manager, Jeddah

European Union/ Research Specialist, Brussels International Medals and Awards

Belgium / King Leopold II. The Order of Merit France / The Legion d'Honneur

The Order of Merit of the Italian Republic / Commendatore

Kyrgyzstan Presidential Academy / Honorary Professorship Languages

English, French

Nationality

Turkish 